\title{
The Effect of Aminothiadiazole on Glycogenesis and Glycogenolysis in Fetal and Neonatal Rat Liver
}

\author{
ALLAN R. BEAUDOIN \\ University of Michigan, Ann Arbor, Michigan 48109
}

\begin{abstract}
The effect of the teratogen 2-amino-1,3,4-thiadiazole on glycogenesis and glycogenolysis was investigated in the fetal and neonatal rat liver. At day 15, 16, or 17 of gestation (sperm day = day 0) pregnant Sprague-Dawley rats received a single IP injection of an aqueous solution of aminothiadiazole. Dosages used were teratogenic $(100 \mathrm{mg} / \mathrm{kg}$ maternal body weight) and nonteratogenic $(10 \mathrm{mg} / \mathrm{kg})$. At day 16 some rats received nicotinamide $(100 \mathrm{mg} / \mathrm{rat})$ in addition to a teratogenic dose of aminothiadiazole. Livers were recovered for assay at fetal day 20 and postnatal day 1 . Only at day 16 did a teratogenic dose induce a significant depression in the fetal activity of glycogen synthetase (to $49.6 \%$ of control activity) and glucose-6-phosphatase (to $72.2 \%$ of control activity), and in glycogen accumulation (to $72.6 \%$ of control accumulation). At day 15 , a teratogenic dose significantly depressed glucose-6-phosphatase activity but not glycogen synthetase activity or glycogen accumulation. Nicotinamide, given immediately after aminothiadiazole, was effective in blocking the inhibition. Teratogenic treatment had no effect on the postnatal activity of glucose-6-phosphatase. Apparently some event associated with birth releases the enzyme from its prenatal inhibition. These results demonstrate a parallelism between the perturbing effect of aminothiadiazole on biochemical development and morphological development with respect to time of insult, dose response, and protection with its antiteratogen. The mechanism of action whereby aminothiadiazole depresses the activity of glycogen synthetase and glucose-6-phosphatase remains to be determined.
\end{abstract}

Biochemical studies of rat embryonic tissue during the organogenetic period have shown several embryotoxic substances to be able to alter normal biochemical development (Neubert et al., '71). What, if any, longterm effect these changes have on subsequent prenatal and postnatal development remains to be determined. The evaluation of perinatal enzymology has been proposed as one method for testing postnatal functional development (Andrew, '76). Alterations in fetal and postnatal enzyme activity have been reported to follow in utero exposure to radiation, chemicals, drugs, hormones, and nutritional deficiency (review by Andrew and Lytz, '81).

Enzymes are indicators of tissue differentiation, and changes in enzyme levels during growth and development have been correlated with the concomitant appearance of function in the embryo (Moog, '70). The sequential emergence of enzymes is necessary to meet the changing functional requirements of the developing organism. Greengard ('70) has described the tendency for the formation of liver enzymes associated with the adaptation to extrauterine life to cluster in time. A cluster forms during the late fetal period (e.g., enzymes of glycogen synthesis and glycogenolysis), a cluster forms during the first day after birth (e.g., enzymes of gluconeogenesis), and a cluster appears during the third week of postnatal life (e.g., enzymes of detoxification and lipid synthesis). It has been proposed that postnatal health and survival (as exemplified by growth and functional normalcy) are determined by the quantitative pattern of enzymes acquired by tissues and organs during fetal and perinatal development (Greengard, '78).

Treatment of pregnant rats with 2-amino1,3,4-thiadiazole (ATDA) induces malforma-

Received January 20, 1983; accepted May 10, 1983. 
tions in their offspring (Beaudoin, '72; Maren and Ellison, '72; Scott et al., '72). In the rat, the period of greatest susceptibility to the teratogenic action of ATDA is from gestation day 9 through day 13 , and the optimal teratogenic dose, without observable maternal effects, is $100 \mathrm{mg} / \mathrm{kg}$ maternal body weight (Beaudoin, '73). The type of malformation induced depends on the developmental stage at the time of treatment. The most frequent malformations observed are anophthalmia, microphthalmia, hydrocephalus, taillessness, ectrodactyly, syndactyly, and cleft palate. A dose of $10 \mathrm{mg} / \mathrm{kg}$ (subteratogenic) fails to induce abnormalities. Aminothiadiazole is an antagonist of nicotinamide (Troy et al., '56). Supplemental nicotinamide treatment protects the rat fetus from the embryolethal and teratogenic effects of ATDA (Beaudoin, '76). Since the usual fate of nicotinamide in the body is incorporation into NAD or its phosphate NADP, it has been suggested that ATDA may interfere with the synthesis or utilization of NAD(P) in cellular metabolism (Beaudoin, '74).

The present study was undertaken to determine if aminothiadiazole, known to induce prenatal morphological damage with resultant congenital malformations, can in duce measurable changes in the biochemical maturation of an organ, and thus perhaps affect postnatal health and survival. The liver was selected as the organ for study because it has been investigated extensively in an attempt to relate biochemistry to function and morphology, and because it is an organ that biochemically reflects adaptations occurring in the transition from intrauterine to extrauterine life.

\section{MATERIALS AND METHODS}

The Sprague-Dawley rat (Charles River, Willmington, Massachusetts) was used in this study. The rats were housed in temperature- and light-controlled animal quarters, and fed Purina Rodent Laboratory Chow (Ralston Purina, St. Louis) ad libitum. Water was available at all times. The day of finding sperm in the vaginal smear was designated day 0 of pregnancy. At day 15, 16 , or 17, pregnant rats received a single IP injection of an aqueous solution of ATDA at a teratogenic dose of $100 \mathrm{mg} / \mathrm{kg}$ maternal body weight. At day 16, additional pregnant rats were treated with either a subteratogenic dose $(10 \mathrm{mg} / \mathrm{kg})$ of ATDA or a teratogenic dose followed immediately by its antiteratogen nicotinamide (100 mg per animal). Con- trol rats received IP injections of a comparable volume of distilled water or nicotinamide. Fetuses were recovered at day 20 for study of enzymes from the late fetal cluster. Newborn animals were selected 1 day after birth for analysis of enzymes of the neonatal cluster. Livers were removed immediately and processed according to the requirements of the enzyme assay. Maternal liver from each control and treated rat were assayed as a check for the procedure. Each assay was run on the liver from a single fetus or newborn. Each enzyme assay included a sample of control maternal liver, experimental maternal liver, control fetal (or newborn) liver, experimental fetal (or newborn) liver, and appropriate blanks and standards. Each sample was run in triplicate.

Glucose-6-phosphatase (E.C. 3.1.3.9) was selected for assay because it is necessary for the release of free glucose from liver cells in the period immediately after birth, when stored glycogen is the only source of glucose. The assay method followed that described by Baginski et al. ('74). Liver is homogenized in ice-cold sucrose solution and the microsomal fraction obtained by centrifugation. The enzyme assay measures spectrophotometrically the inorganic phosphate liberated in the breakdown of glucose-6-phosphate. Enzyme activity is expressed as $\mu$ moles of phosphate liberated per minute per gram of liver.

Uridine diphosphate glucose glycogen glycosyltransferase (glycogen synthetase, E.C. 2.4.1.11) was selected because it appears at the time of initial glycogen synthesis. Liver is homogenized and, following centrifugation, the supernatant is assayed according to the procedure described by Leloir and Goldemberg ('62), which depends on the production of uridine disphosphate from UDPG. Enzyme activity is expressed as $\mu$ moles UDP per minute per gram of liver.

Glycogen was selected because of its rela tionship to the two enzymes assayed and because of its importance as an energy source for the newborn rat. Glycogen concentration in fetal and maternal liver was determined by the method of Carroll et al. ('56), using the anthrone reagent.

The results were analyzed statistically using the one-tailed Student's " $t$ " distribution (Brown and Hollander, '77).

\section{RESULTS}

Male and female fetuses were assayed separately but, because there were no significant differences between the results in any 
assay, these results are grouped together in the tables. Both adult and fetal enzyme activities reported in this paper for the normal livers are within the range reported for these enzymes in rats (Knox, '72). The $\mathrm{H}_{2} \mathrm{O}$-treated controls were pooled in the study of each enzyme.

\section{Glycogen synthetase}

Enzyme activity in the maternal liver ranged between 1.20 and $2.56 \mu$ moles $/ \mathrm{min} / \mathrm{g}$ of liver. ATDA treatment had no effect on enzyme activity in the maternal liver when activity was measured at the time of fetus recovery, 4 days after the injection. Table 1 presents the data for glycogen synthetase activity in fetal liver following maternal injection with distilled water, nicotinamide, or ATDA at day 15,16 , or 17 of gestation. A teratogenic dose of ATDA administered at day 15 or 17 had no significant effect on enzyme activity; a teratogenic dose administered at day 16 , however, caused a marked depression in enzyme activity at day 20 , to $50 \%$ of control values $(\mathrm{P}=0.0005)$. A subteratogenic dose of $10 \mathrm{mg} / \mathrm{kg}$ depressed glycogen synthetase activity to $84 \%$ of control values, but the depression was not statistically significant. Supplementation with nicotinamide was effective in blocking the enzyme depressing action of $100 \mathrm{mg} / \mathrm{kg}$ ATDA.

\section{Glucose-6-phosphatase}

Enzyme activity in maternal livers ranged between 4.4 and $12.5 \mu \mathrm{moles} / \mathrm{min} / \mathrm{g}$ of liver. ATDA treatment had no effect on enzyme activity in the maternal liver when activity was measured at the time of fetus recovery, 4 days after the injection. Table 2 presents the data for glucose-6-phosphatase activity in fetal liver following maternal treatment with distilled water, nicotinamide, or ATDA at day 15,16 , or 17 of gestation. ATDA caused a marked depression in fetal enzyme activity at day 20 to $72 \%$ of control values $(\mathrm{P}=$ 0.0005 ), when injection was at day 15 or 16 . Maternal ATDA injection at day 17 had no significant effect on enzyme activity at day 20. A subteratogenic dose of $10 \mathrm{mg} / \mathrm{kg}$ at day 16 had a marginal depressing effect on enzyme activity, in contrast to the results observed with glycogen synthetase. The administration of the nicotinamide supplement immediately after the injection of a teratogenic dose of ATDA prevented its enzyme-inhibiting action. Compared with the pooled water controls, there was a slight decrease in enzyme activity following treatment with nicotinamide alone at day 16 . This decrease, however, is barely significant $(\mathrm{P}=$ 0.05 ), and only two litters were studied. After birth the enzyme is apparently released from the inhibitory effect of ATDA, for although a slight depression in activity was found, the depression was not significantly lower than activity observed in the control newborns (Table 3).

Table 4 presents the data for glycogen accumulation in fetal livers following maternal treatment with distilled water, nicotinamide, or ATDA at day 15 or 16 of gestation. The rats used for glycogen determination are the

TABLE 1. Glycogen synthetase activity in the day-20 fetal rat liver

\begin{tabular}{|c|c|c|c|c|}
\hline Treatment & $\begin{array}{l}\text { No. dams } \\
\text { treated }\end{array}$ & $\begin{array}{l}\text { No. fetuses } \\
\text { assayed }\end{array}$ & $\begin{array}{l}\text { Activity } \\
\pm \text { SEM }^{1}\end{array}$ & Percent control \\
\hline $\begin{array}{c}\mathrm{H}_{2} \mathrm{O} \text { pooled } \\
\text { controls }\end{array}$ & 13 & 94 & $4.25 \pm 0.21$ & \\
\hline \multicolumn{5}{|c|}{ ATDA (100 mg/kg) } \\
\hline $\begin{array}{l}\text { Day } 15 \\
\text { Day } 16\end{array}$ & $\begin{array}{l}6 \\
8\end{array}$ & $\begin{array}{l}24 \\
30\end{array}$ & $\begin{array}{l}4.04 \pm 0.20 \\
2.11 \pm 0.24\end{array}$ & \multirow{2}{*}{$\begin{array}{c}95.0 \\
49.6 \\
(\mathrm{P}=0.0005) \\
101.8\end{array}$} \\
\hline Day 17 & 8 & 32 & $4.33 \pm 0.31$ & \\
\hline $\begin{array}{l}\text { ATDA }(10 \mathrm{~m} \\
\text { Day } 16\end{array}$ & /kg) & 24 & $3.58 \pm 0.56$ & 84.2 \\
\hline \multicolumn{4}{|c|}{ Nicotinamide } & \\
\hline \multicolumn{5}{|c|}{ ATDA (100 mg/kg) } \\
\hline Day 16 & 3 & 12 & $4.50 \pm 0.43$ & $\begin{array}{c}104.6 \\
(\% \mathrm{~N} \text { control })\end{array}$ \\
\hline
\end{tabular}

${ }^{{ }} \mu \mathrm{moles} \mathrm{UDP} / \mathrm{min} / \mathrm{g}$ liver. 
TABLE 2. Glucose-6-phosphatase activity in the day-20 fetal rat liver

\begin{tabular}{|c|c|c|c|c|}
\hline Treatment & $\begin{array}{c}\text { No. dams } \\
\text { treated }\end{array}$ & $\begin{array}{c}\text { No. fetuses } \\
\text { assayed }\end{array}$ & $\begin{array}{l}\text { Activity } \\
\pm \text { SEM }^{1}\end{array}$ & Percent control \\
\hline $\begin{array}{c}\mathrm{H}_{2} \mathrm{O} \text { pooled } \\
\text { controls }\end{array}$ & 16 & 99 & $0.36 \pm 0.01$ & \\
\hline \multicolumn{5}{|c|}{ ATDA $(100 \mathrm{mg} / \mathrm{kg})$} \\
\hline Day 15 & 3 & 16 & $0.26 \pm 0.02$ & $(\mathrm{P}=0.0005)$ \\
\hline Day 16 & 8 & 32 & $0.26 \pm 0.01$ & $\begin{array}{c}72.2 \\
(P=0.0005)\end{array}$ \\
\hline Day 17 & 8 & 21 & $0.33 \pm 0.005$ & 91.6 \\
\hline \multicolumn{5}{|c|}{ ATDA (10 mg/kg) } \\
\hline Day 16 & 3 & 16 & $0.31 \pm 0.02$ & $\begin{array}{c}86.1 \\
(\mathbf{P}=0.02)\end{array}$ \\
\hline Nicotinamide & 2 & 17 & $0.31 \pm 0.01$ & \\
\hline \multicolumn{5}{|c|}{ ATDA $(100 \mathrm{mg} / \mathrm{kg})$} \\
\hline Day 16 & 4 & 16 & $0.33 \pm 0.02$ & $\begin{array}{c}104.6 \\
(\% \mathrm{~N} \text { control) }\end{array}$ \\
\hline
\end{tabular}

' $\mu$ moles phosphate liberated/min/g liver.

TABLE 3. Glucose-6-phosphatase activity in newborn rat liver following maternal treatment with ATDA

\begin{tabular}{lcccc}
\hline Treatment & $\begin{array}{c}\text { No. dams } \\
\text { treated }\end{array}$ & $\begin{array}{c}\text { No. fetuses } \\
\text { assayed }\end{array}$ & $\begin{array}{c}\text { Activity } \\
\pm \text { SEM }^{1}\end{array}$ & $\begin{array}{c}\text { Percent } \\
\text { control }\end{array}$ \\
\cline { 3 - 6 } Day 16 & & & & \\
$\mathrm{H}_{2} \mathrm{O}$ & 4 & 28 & $6.65 \pm 0.63$ & \\
ADTA $(100 \mathrm{mg} / \mathrm{kg})$ & 5 & 37 & $5.99 \pm 0.48$ & 90.1 \\
\hline
\end{tabular}

${ }^{\prime} \mu$ moles phosphate liberated $/ \mathrm{min} / \mathrm{g}$ liver.

$T A B L E$ 4. Glycogen concentration in the day-20 fetal rat liver

\begin{tabular}{|c|c|c|c|c|}
\hline Treatment & $\begin{array}{c}\text { No. dams } \\
\text { treated }\end{array}$ & $\begin{array}{c}\text { No. fetuses } \\
\text { assayed }\end{array}$ & $\begin{array}{l}\text { Amount } \\
\pm \text { SEM }^{1}\end{array}$ & Percent control \\
\hline $\begin{array}{l}\mathrm{H}_{2} \mathrm{O} \text { pooled } \\
\text { controls }\end{array}$ & 6 & 24 & $26.52 \pm 1.26$ & \\
\hline \multicolumn{5}{|c|}{ ATDA $(100 \mathrm{mg} / \mathrm{kg})$} \\
\hline Day 15 & 2 & 7 & $25.79 \pm 2.31$ & 97.2 \\
\hline Day 16 & 4 & 16 & $19.27 \pm 0.98$ & $\begin{array}{c}72.6 \\
(\mathrm{P}=0.01)\end{array}$ \\
\hline $\begin{array}{l}\text { Nicotinamid } \\
(100 \mathrm{mg})\end{array}$ & 4 & 15 & $26.20 \pm 2.67$ & \\
\hline \multicolumn{5}{|c|}{$\begin{array}{l}\text { ATDA }(100 \mathrm{mg} / \mathrm{kg}) \\
+\mathrm{N}(100 \mathrm{mg})\end{array}$} \\
\hline Day 16 & 3 & 11 & $28.38 \pm 4.17$ & $\begin{array}{c}108.3 \\
(\% \mathrm{~N} \text { control })\end{array}$ \\
\hline
\end{tabular}

${ }^{1} \mathrm{mg} / \mathrm{r}$ liver. 
same rats used for glycogen synthetase assay, except that glycogen was not measured in all fetuses in which the enzyme was assayed. A teratogenic dose administered at day 15 had no effect on fetal glycogen accumulation when measured at day 20 . An identical dose of ATDA at day 16, however, markedly reduced glycogen deposits to $73 \%$ of control values $(\mathrm{P}=0.01)$. Supplemental treatment with nicotinamide immediately following ATDA injection abolished the inhibitory effect of ATDA, and glycogen accumulation was similar to that observed in control fetuses.

\section{DISCUSSION}

The accumulation of liver glycogen in the late fetal period, its rapid utilization after birth, and persistent low blood glucose levels during the neonatal period are a common pattern in mammals during the transition from intrauterine to extrauterine existence (Dawkins, '66). The importance of this glucose is demonstrated following radiation-induced deletions in chromosome 7 in the mouse. The offspring die shortly after birth because they cannot maintain a normal blood glucose level owing to the absence of glucose6-phosphatase activity in the liver (Gluecksohn-Waelsch, '79). Events associated with birth induce within hours a rapid fall in liver glycogen to a concentration of $10 \%$ or less of the fetal concentration, where it remains for several days, attaining the adult level in 23 weeks (Shelly, '61). The glucose released is utilized by the newborn as an energy source until nutrients are absorbed from the gut following suckling.

It is known that prenatal insult may produce changes in postnatal physiology and behavior, and that these changes may be subtle (Rodier, '78). It is probable that biochemical alterations underlie these changes, but, while the calendar for prenatal and postnatal morphological development is well known, the timing of the biochemical events that precede morphological and functional events during development is not well known, and little has been written about the effect of teratogens on the biochemical maturation of organs.

It can be expected that if teratogens do affect biochemical differentiation, the effects will parallel those seen during morphological differentiation with respect to dosage, timing of insult, genotype, etc. The results of the present experiment demonstrate that a teratogenic agent can interfere with the time- table of biochemical maturation of an organ. A teratogenic dose of ATDA inhibited the activity of the enzymes' glycogen synthetase and glucose-6-phosphatase in the rat fetal liver without altering their activity in maternal liver. The accumulation of fetal liver glycogen was simultaneously reduced. The latter was expected since glycogen synthetase is the enzyme in the rate-limiting step for the formation of glycogen. These effects were time-specific. The susceptible period for the induction of enzyme depression appears to vary between the two enzymes studied. Following maternal injection at day 16 , a teratogenic dose of ATDA inhibited the activity of both glycogen synthetase and glucose-6 phosphatase. Maternal injection at day 15, however, only depressed glucose-6-phosphatase activity. Neither enzyme was affected by ATDA treatment at day 17. A dose response was demonstrated. A teratogenic dose was an effective enzyme-inhibitory dose. A subteratogenic dose failed to inhibit glycogen synthetase significantly but did slightly inhibit glucose-6-phosphatase. The significance of these observations remains to be determined but may reflect differing sensitivities to ATDA in the two pathways of enzyme synthesis. This is reminiscent of the development of different organs that have differing susceptibilities to teratogenic influence. The effect of the teratogen on both enzyme activity and glycogen accumulation could be abolished by supplementation with nicotinamide, an antiteratogen against ATDA. These results demonstrate that, in the rat, a parallelism exists between the perturbing effect of ATDA on biochemical development and morphological development.

It has been recently demonstrated (Kavlock et al., '82) that several fetotoxic agents administered to the dam during the organogenetic period cause decreased glycogen deposition in fetal rat liver late in gestation. Snell et al. (77) have shown the administration of methyl mercury at day 8 of gestation in rats to depresss the activity of glucose-6 phosphatase during the late fetal period. The postnatal activity of glucose-6-phosphatase has been reported to be reduced following irradiation in utero in rats (Smith and Shore, '66) and beagles (Wagner and Garner, '71). The results in the present experiment differ in that the prenatally induced reduction in activity of glucose-6-phosphatase did not persist postnatally. To demonstrate that the enzyme depression peristed until birth, two pregnant rats were treated at day 16 with a 
teratogenic dose of ATDA. The dams were allowed to deliver five pups each after which the fetuses remaining in utero were recovered. Livers were removed immediately. The activity of glucose-6-phosphatase was assayed and found to be depressed in the livers of the fetuses in utero but comparable to control activity in the livers of the recently born pups (unpublished). Apparently some event associated with the birth process releases the enzyme from the inhibitory effect of ATDA. This event remains to be identified.

The use of aminothiadizole as a teratogen during rat development in utero has revealed two periods of susceptibility. Early in gestation ATDA perturbs morphological development, and late in gestation it perturbs biochemical development. Within each susceptible period, the observed response varies with the time of insult and the dose. In addition, nicotinamide blocks both actions of ATDA. The mechanism whereby aminothiadiazole depresses enzyme activity remains to be elucidated.

\section{ACKNOWLEDGMENTS}

The technical assistance of Kevin S. Holton is gratefully acknowledged.

\section{LITERATURE CITED}

Andrew, F.D. (1976) Techniques for assessment of tera togenic effects: Developmental enzyme patterns. Environ. Health Perspect., 18:111-116.

Andrew, F.D., and P.S. Lytz (1981) Biochemical distur. bances associated with developmental toxicity. In: Developmental Toxicology. C.A. Kimmel and J. BuelkeSam, eds. New York, Raven Press, pp. 145-165.

Baginski, E.S., P.O. Foa, and B. Zak (1974) Glucose-6phosphatase. In: Methods of Enzymatic Analysis. H.U. Bergmeyer, ed. New York, Academic Press, Vol, 2, pp 876-880.

Beaudoin, A.R. (1972) Teratogenic action of 2-amino-1,3,4thiadiazole in rats. Teratology, 5:250 (abstract).

Beaudoin, A.R. (1973) Teratogenic activity of 2-amino1,3,4-thiadiazole hydrochloride in Wistar rats and the protection afforded by nicotinamide. Teratology, 7: 65-72.

Beaudoin, A.R. (1974) Thiadiazole-induced myelodysplasia in rats. Teratology, 9:179-189.

Beaudoin, A.R. (1976) NAD precursors as antiteratogens against aminothiadiazole. Teratology, 13:95-100.

Brown, B.W. Jr., and M. Hollander (1977) Statistics. New York, John Wiley.
Carroll, N.V., R.W. Longley, and J.H. Roe (1956) The determination of glycogen in liver and muscle by use of anthrone reagent. J. Biol. Chem., 220:583-593.

Dawkins, M.J.R. (1966) Biochemical aspects of develop. ing function in new-born mammalian liver. Br. Med. Bull, 22:27-33.

Gluecksohn-Waelsch, S. (1979) Genetic control of morphogenetic and biochemical differentiation: Lethal albino deletions in the mouse. Cell, 16:225-237.

Greengard, O. (1970) The developmental formation of enzymes in rat liver. In: Biochemical Actions of Hormones. G. Litwack, ed. New York, Academic Press, pp. 53-87.

Greengard, O. (1978) Relationship of enzymes to normal and abnormal fetal growth. In: Abnormal Fetal Growth: Biological Bases and Consequences. F. Naftolin, ed. Berlin, Dahlem Konferenzen, pp 165-186.

Kavlock, R.J., N. Chernoff, E. Rogers, D. Whitehouse, B. Carver, J. Gray, and K. Robinson (1982) An analysis of fetotoxicity using biochemical endpoints of organ differentiation. Teratology, 26:183-194.

Knox, W.E. (1972) Enzyme Patterns in Fetal, Adult, and Neoplastic Rat Tissues. Basel, S. Karger.

Leloir, L.F., and S.H. Goldemberg (1962) Glycogen synthetase from rat liver. In: Methods in Enzymology. S.P. Colowick and N.O. Kaplan, eds. New York, Academic Press, Vol. 5, pp. 145--147.

Maren, T.H., and A.C. Ellison (1972) The teratological effect of certain thiadiazoles related to acetazolamide, with a note on sulfanilamide and thiazide diuretics. Johns Hopkins Med. J., 130:95-104.

Moog, F. (1970) Enzyme development and functional differentiation in the fetus. In: Fetal Growth and Devel. opment. H.A. Waisman and G.R. Kerr, eds. New York, McGraw-Hill, pp. 29-48.

Neubert, C., H.J. Merker, E. Kohler, R. Krowke, and H.J. Barrach (1971) Biochemical aspects of teratology. Adv. Biosci., 6:575-622.

Rodier, P.M. (1978) Behavioral teratology. In: Handbook of Teratology. J.G. Wilson and F.C. Fraser, eds. New York, Plenum, Vol. 4, pp. 397-428.

Scott, W.J., J.G. Wilson, and E.J. Ritter (1972) The teratogenic, biochemical, and histological effects of ami nothiadiazole and their reversibility by nicotinamide. Teratology, 5:206 (abstract).

Shelly, H.J. (1961) Glycogen reserves and their changes at birth and in anoxia. Br. Med. Bull., 17:137-143.

Smith, C.H., and M.I. Shore (1966) Impaired development of rat liver enzyme activities at birth after irra diation in utero. Radiat. Res., 29:499-504.

Snell, D., S.L. Ashby, and S.J. Barton (1977) Disturbances of perinatal carbohydrate metabolism in rats exposed to methylmercury in utero. Toxicology, 8:277283.

Troy, W.P., A.S. Sloboda, S.L. Halliday, and J.J. Oleson (1956) Derivatives of 2-amino-1,3,4-thiadiazole as niacin antagonists. Fed. Proc., 15:372 (abstract).

Wagner, M.T., and R.J. Garner (1971) The effect of prenatal $\gamma$-irradiation of postnatal enzyme development in the beagle. Radiat. Res., 46:380-393. 